\title{
A Time-Varying Risk Analysis of Equity and Real Estate Markets in the U.S. and Japan
}

\author{
Crocker H. Liu, New York University, \\ Jianping (J.P.) Mei, New York University
}

The paper offers some new evidence which suggests that Japanese equity and real estate markets might not necessarily behave in a parallel manner to US capital markets. These results are obtained from an examination of the nature of expected and unexpected movements in the returns of Japanese assets and US assets using a present-value model which allows for a time-varying expected discount rate in conjunction with a VAR process. Based on data from 1972-92, it is found that one distinctive difference is that changes in the future expected return for Japanese real estate and stocks are less persistent over time than their US counterparts. It is also found that the impact of Japanese markets on the US market was relatively small. On the other hand, there is some evidence that the US equity market had some significant impact on the Japanese equity market. Returns on Japanese stocks also exhibit a weaker mean reversion process relative to returns on US stocks and US real estate.

\section{Introduction}

Globalization of the world financial markets has raised the interesting question as to the extent the US and Japanese asset markets resemble one another. One area of particular academic interest is whether innovations in macroeconomic factors which serve as proxies for underlying risk factors that drive US stock returns are portable to the Japanese equity market. ${ }^{1} A$ related area of interest for which little evidence exists for Japan involves what moves capital markets (especially the real estate market);

\footnotetext{
${ }^{1}$ For example, Elton and Gruber (1990) find that four factors associated with macroeconomic variables are evident in Japanese stock returns although none of the factors appear to imply positive risk premia. Hamao et al. (1990) find that the similar macroeconomic factors influence both the US and Japanese markets. In particular, changes in expected inflation, unanticipated changes in risk premium and in the term structure's slope, changes in monthly production, and terms of trade are associated with positive risk premia while oil price changes and unanticipated changes in foreign exchange are not priced in the Japanese equity market. Brown and Otsuki (1990) also find evidence that six to seven macrofactors are priced sources of risk in the Japanese market using the paradigm of McElroy and Burmeister (1988) together with a VAR process. Campbell and Hamao (1991) in a related paper find that excess returns on both US and Japanese stocks are predictable using similar sets of macroeconomic variables.
} 
e.g. why do prices change in a given manner $?^{2}$ More specifically, what proportion of the variation in total returns is attributable to the variance of contemporaneous expected returns and what percentage is associated with the variance of unexpected returns? To what extent does cash flow risk and discount rate risk account for movements in unexpected returns?

The purpose of the current study is to examine movements in the prices of Japanese equity and real estate stocks and to compare these movements with price fluctuations for their US counterparts using the present-value model of Campbell $(1987,1991)$ which allows the expected discount rate to vary through time in conjunction with a vector autoregressive (VAR) process. One key issue explored is whether the relative influence of the variance in news about future returns and the variance in news about future dividends for Japanese equity and real estate markets is similar to that for US markets. In particular, are movements in the Japanese capital markets driven primarily by news about the future expected return (discount rate) or by news about future cash flows? How persistent over time are changes in the expected rate of return; e.g. for how many periods does a drift occur in expected returns? Another related issue investigated is whether strong negative serial correlation exists for Japanese equity and real estate returns given evidence that investors can successfully profit from using a contrarian investment strategy for US capital markets in the short run. We analyze real estate in addition to stocks, since prior studies such as Hamao and Hoshi (1991) and Liu and Mei (1992) find that the return characteristics of stocks are not necessarily similar to real estate returns. Moreover, the value of land represents a major portion of the market wealth in every country. Boone and Jeffrey (1989) report that not only is the land value of Japan three times Japan's GNP, but also the average unit price for a Japanese parcel is 90 times that of comparable land in the United States. However, Boone and Jeffrey also observe that the value of land relative to GNP is similar in each country.

We find that Japanese stocks and real estate differ in several important respects from their US counterparts. One distinguishing intercountry aspect is that current Japanese stock returns are useful in predicting future expected returns on Japanese real estate while existing returns on US real estate are valuable in forecasting future anticipated returns on US stocks. Another notable feature is that news on

\footnotetext{
${ }^{2}$ One of the few studies which address this issue is Campbell (1991) who decomposes movements in unexpected US stock returns into the variance in news about future cash flows and the variance in news about future returns using a vector autoregressive system together with a present-value model. Campbell finds that the variance of news about future cash flows accounts for only 33-50 percent of the fluctuations in unexpected returns with the remainder attributable to variations in news about future expected returns. Campbell and Ammer (1991) extend Campbell (1991) to address what moves stock and bond markets, while Liu and Mei (1991) examine the extent to which cash flow risk, discount rate risk, and the covariance between these two types of risk are different for large stocks, small stocks, and real estate in the US market.
} 
future cash flows account for a major portion of the variation in unexpected returns on Japanese stocks and real estate. News on future expected returns, in contrast, have a greater impact on returns on US stocks and real estate. A further distinction between countries is that changes in the future expected discount rate is less persistent over time for Japanese real estate and stocks relative to their US counterparts even though returns on Japanese assets are at least as predictable as returns on US assets. Consequently, changes in the future expected returns have a greater impact on current prices for US relative to Japanese stocks and real estate. A final differentiating result is that returns on Japanese stocks exhibit weaker negative serial correlations relative to returns on US stocks and real estate. Japanese real estate, in contrast, appears to have fairly strong positive serial correlations over the period examined. Thus, a contrarian investment strategy is less likely to be profitable in the short run for stocks and real estate in Japan relative to the US. This result appears to have been confirmed by the drawn-out recession in the Japanese equity and real estate market for the last nine years.

However, we do find some parallels between stocks and real estate in the US and Japan. Most of the variation in total returns for these assets in both countries is attributable to the variance in unexpected stock returns, although the anticipated volatility in real estate returns accounts for a larger portion of the movement in returns in the US and Japan. Besides this, returns on real estate are more predictable relative to stock returns in both countries. Changes in the expected return on real estate are more persistent over time compared with stocks in each country. The return on real estate also exhibits less negative serial correlations relative to stocks in both the US and Japan.

The remainder of the paper is organized as follows. The next section discusses the framework used to view the relationship between unexpected returns and movements in expected returns. This section also describes the VAR approach used to decompose the variance of Japanese stock returns into news about future cash flows and news about future expected returns. Section 3 describes our dataset. Our empirical results, including the extent to which variations in unexpected returns for Japanese securities are associated with different types of news, are reported in section 4 . Section 5 concludes the study.

\section{Basic Framework and Estimation Process}

The approximate present-value model of Campbell (1991) is used to characterize the relationship between the unexpected real asset return in the next period $(t+1)$ and changes in rational expectations of future dividend growth and future asset returns. More formally, the fundamental equation is 


$$
h_{t+1}-E_{t} h_{t+1}=\left(E_{t+1}-E_{t}\right) \sum_{j=0}^{\infty} \rho^{j} \Delta d_{t+1+j}-\left(E_{t+1}-E_{t}\right) \sum_{j=1}^{\infty} \rho^{j} h_{t+1+j}
$$

where $\mathrm{E}_{\mathrm{t}}$ is the expectation formed at the end of period $t, h_{t+1}$ represents the log of the real return on an asset held from the end of period $t$ to the end of period $t+1, d_{t+1}$ is the log of the real dividend paid during period $t+1$, A denotes a one-period backward difference, and $\left(E_{t+1}-E_{t}\right)$ represents a revision in expectations given that new information arrived at time $t+1$. The parameter $p$ is a constant and is constrained to be smaller than one. ${ }^{3}$ A more detailed derivation of the model is given in the Appendix. The main point of equation (1) is that if the unexpected return on an asset is negative given that expectations are internally consistent, then it follows that either the expected future growth in dividends must decrease, the expected future returns (discount rate) on the stock must increase, or both phenomena must occur.

For our study, we will use a more compact version of equation (1) written as follows: $v_{h, t+1}=\eta_{d, t+1}-\eta_{h, t+1}$ where $v_{h, t+1}$ is the unexpected component of the stock return $h_{t+1}, \eta_{d, d+1}$ represents news about cash flows, and $\eta_{h, t+1}$ represents news about future returns (discount rate).

We model eight economic state variables including the real monthly returns on stocks and real estate, the nominal return on government bills, and the dividend yield for the US and Japan according to a border vector autoregressive (VAR) process given that the VAR process provides a useful framework to summarize data. ${ }^{4}$ As in previous studies, we include the nominal return on government bills to capture information on the short-term interest rate, and the dividend yield which provides information on expectations about future cash flows and required returns in the stock market. ${ }^{5}$ The real return on real estate is included in the study given that Hamao and Hoshi (1991) find that real estate market conditions help explain the time-variation in ex-ante Japanese equity returns, and vice versa.

\footnotetext{
${ }^{3} 3$ The model is derived using a first-order Taylor approximation of the present-value equation which relates the $\log$ of asset returns to the log of asset prices and dividends. To solve the resulting equation using a forward process, a terminal condition is imposed which does not allow the log of the dividend/price ratio to follow an explosive process.

${ }^{4}$ The VAR approach assumes that each variable in the process is a stationary time-series and as such can be modelled using an autoregressive (AR) model. The fact that lagged state variables are present in an autoregressive process is not necessarily contradictory to market efficiency if the risk premiums paid on assets vary over time owing to changing economic conditions. If this is the case, then the lagged variables in the VAR process serve as a proxy for the economic state variables that drive the risk premium and this also provides us with some clue as to what are the relevant variables to include in the VAR model of asset pricing dynamics.

${ }^{5}$ See Campbell (1990), Campbell and Hamao (1991), Campbell and Mei (1991), Fama and French (1989), and Hamao (1989).
} 
The VAR process initially involves defining a vector $z_{t+1}$ which has $k$ elements, the first of which are the real asset returns $h_{t+1}$ in consideration and additional elements in this vector are other variables which are known to the market at the end of period $t+1$. Although we initially model asset returns under the assumption that the vector $z_{t+1}$ follows a first-order VAR process shown in equation (3) below, we later relax this assumption:

$z_{t+1}=A z_{t}+w_{t+1}$

Higher-order VAR models that we employ are stacked into this VAR (1) model in the same manner as discussed in Campbell and Shiller (1988). In equation (3), the matrix A is known as the companion matrix of the VAR.

In addition to the vector $z_{t+1}$, we also define a it-element vector $e_{1}$ whose elements are all zero except the first element which is 1 . The vector et is used to separate out real asset returns $h_{t+1}$ from the vector $z_{t+1}$ (e.g. $h_{t+1}=e_{\mid} z_{t+1}$ ) and to extract the unexpected component of real asset returns $v_{h, t+1}=e_{1} w_{t+1}$ from the residual vector $\left(w_{t+1}\right)$ of the VAR process. The VAR(I) approach produces intertemporal predictions of future returns:

$$
E_{t} h_{t+1+j}=\mathbf{e}^{\prime}{ }^{\prime} \mathbf{A}^{j+1} \mathbf{z}_{t}
$$

From equation (4), it follows that we can define news about future returns or discount rates (the present-value of the revisions in forecasted returns) as

$$
\begin{aligned}
\eta_{h, t+1} \equiv\left(E_{t+1}-E_{t}\right) \sum_{j=1}^{\infty} \rho^{j} h_{t+1+j} & =\mathbf{e}_{1}{ }^{\prime} \sum_{j=1}^{\infty} \rho^{\mathrm{j}} \mathbf{A}^{j} \mathbf{w}_{t+1}=\mathbf{e}_{1}^{\prime} \rho \mathbf{A}(\mathbf{I}-\rho \mathbf{A})^{-1} \mathbf{w}_{t+1} \\
& =\lambda^{\prime} \mathbf{w}_{t+1}
\end{aligned}
$$

where $\lambda=e_{1} p A(I-p A)^{-1}$ and is a nonlinear function of the VAR coefficients. In addition to this, given that the first element of $\mathrm{w}_{\mathrm{t}+1}$ is $\mathrm{v}_{\mathrm{h}, t+1}=\mathrm{e}_{1} \mathrm{w}_{\mathrm{t}+1}$, equations (5) and (2) imply that we can write news about cash flows as follows:

$$
\eta_{d, t+1}=\left(\mathbf{e}_{1}^{\prime}+\lambda^{\prime}\right) \mathbf{w}_{t+1}
$$

We will use the expressions in equations (5) and (6) to decompose the variance of unexpected asset returns $\left(v_{h, t+1}\right)$ for each stock portfolio into the variance of the news about cash flow $\left(\eta_{d, t+1}\right)$, the variance of the news about expected returns $(\%,+$,$) , and a covariance term. As in Campbell (1991), we$ will use the following persistence measure $P_{h}$ associated with the VAR process as our measure of the persistence of expected returns: 


$$
P_{h} \equiv \frac{\sigma\left(\eta_{h, t+1}\right)}{\sigma\left(u_{t+1}\right)}=\frac{\sigma\left(\lambda^{\prime} \mathbf{w}_{t+1}\right)}{\sigma\left(\mathbf{e}_{1}^{\prime} \mathbf{A} \mathbf{w}_{t+1}\right)}
$$

where $u_{t+1}=\left(E_{t+1}-E_{t}\right) h_{t+2}$ denotes innovations in the one-period-ahead expected return and $a(x)$ denotes the standard deviation of $x$. This measure represents the volatility of the news about expected returns relative to the variability of the innovation in the one-period-ahead expected return. We can interpret the persistence measure as follows: a Ph percent capital loss on the stock will result given a 1 percent positive innovation in the expected return. The intuition underlying this persistence measure is that if changes in expected returns are temporary, then it will not impact significantly on the news about future expected returns $\eta_{h, t+1}$. Otherwise, it will have a major impact on stock returns owing to its effect on discount rates.

In addition to decomposing the variance of unexpected returns and determining to what extent expected returns persist on an intertemporal basis, we utilize a variance ratio test to ascertain if Japanese stock and real estate returns exhibit mean-reverting behavior similar to that for their US counterparts. ${ }^{6}$ The variance ratio statistic $V(K)$, which is defined as the ratio of the variance of oneperiod returns to the variance of one-period returns, divided by $K$, can be calculated directly from the autocorrelations of one-period returns by using the fact that

$$
V(K)=1+2 \sum_{j=1}^{K-1}\left(1-\frac{j}{K}\right) \operatorname{Corr}\left(h_{t}, h_{t-j}\right) .
$$

The variance ratio equals 1 for white noise returns (i.e. there is no serial correlation in the return series, so Corr $\left.\left(h_{t} h_{t-j}\right)=0\right)$; it exceeds 1 when returns are mostly positively autocorrelated, and it is below 1 when negative autocorrelations dominate.

The generalized method of moments of Hansen (1982) is used to jointly estimate the VAR coefficients and the elements of the variance-covariance matrix of VAR innovations. To calculate the standard errors associated with estimation error for any statistic, we first let $\checkmark$ and $V$ represent the whole set of parameters and the variance-covariance matrix respectively. Next, we write any statistic, such as the covariance between news about future expected returns and discount rates, as a nonlinear function $f(\gamma)$ of the parameter vector $\Upsilon$. The standard error for the statistic is then estimated as $\left.\sqrt{f_{Y}(Y) V f_{Y}}(Y)\right]$

\footnotetext{
${ }^{6}$ Campbell (1990), Cochrane (1988), Lo and MacKinlay, (1988) and Poterba and Summers (1988), have all used the variance ratio test to document the mean reverting behavior of stock returns. Kandel and Stambaugh (1988) also report a number of calculations of this type.
} 


\section{The Data}

Monthly returns on value-weighted stocks, returns on government bills, the dividend yield, and the rate of inflation for Japan are obtained from Hamao/ Ibbotson and Associates Stocks, Bonds, and Inflation 1989 Japan Yearbook and updates to that yearbook. In addition to this, monthly returns for Japanese real estate are derived using the real estate index taken from the Nikkei Telecom News Retrieval system which reports Japanese stock price indices by industry for the first section of the Tokyo Stock Exchange. ${ }^{7}$ Returns on this Japanese real estate security index do provide information on conditions in the underlying real estate market given that correlations of the absolute levels of this Japanese real estate index with the Japanese CPI housing index and also the Japanese Real Estate Institute (JREI) indices used in the Hamao and Hoshi (1991) reveal correlations ranging from 0.78 for the JREI indices to 0.97 for the CPI housing index.

Data on monthly US stock returns, dividend yields, yields on one-month Treasury bills, and the rate of inflation are taken from Ibbotson and Associates Stocks, Bonds, Bills, and Inflation series on the CRSP tape. To proxy for real estate returns in the US, we use the value-weighted equity real estate investment trust (REIT) series published by the National Association of Real Estate Investment Trusts (NAREIT). ${ }^{8}$ The NAREIT index includes all equity REITs, not just those having a continuous price history over the period in question to avoid the problem of survivorship bias. Gyourko and Keim (1992) have shown that lagged equity REIT returns are useful in predicting appraisal-based real estate returns and that equity REIT returns are contemporaneously correlated with the National Association of Realtors (NAR) existing home sales appreciation rate. Fisher et al. (1991) find that appraisal-based series such as the Frank Russell Company (FRC) index move very closely with the NAREIT index after "de-smoothing" the appraisal-based series, while Mei and Lee (1993) also discover that the FRC index and equity REITs are driven by common real estate factors. Consequently, these studies indicate that returns on securitized real estate represent good proxies for returns to the underlying real estate.

\footnotetext{
${ }^{7}$ Japanese stocks included in the real estate index include Mitsui Real Estate Development, Mitsubishi Estate, Tokyo Tatemono, Osaka Building, Sankei Building, Tokyu Land, Kakuei Construction, Daiwa Danchi, Sumitomo Realty and Development, Odakyu Real Estate, Toho Real Estate, Towa Real Estate Development, Taiheiyo Kouhatsu, Nichimo, Daikyo, TOC, and Tokyo Rakutenchi.

${ }^{8}$ An equity REIT is analogous to a closed-end investment company for investors who want to participate in the ownership of real estate. A REIT is not taxed on distributed taxable income if it satisfies certain provisions, including the fact that at least 95 percent of net annual taxable income must be distributed to shareholders.
} 
Returns on stocks and real estate in both countries are deflated using the respective owncountry rate of inflation. The resulting returns on Japanese stock and real estate are then denominated in US dollars. All of the series used start in February 1972 and end in February 1992.

\section{Empirical Results}

Table 1 provides summary statistics on and correlations among real returns for Japanese and US value-weighted stocks and real estate securities as well as for our other forecasting variables denominated in US dollars. While real estate exhibits a lower risk and higher returns relative to stocks in the US which is consistent with the findings of Liu and Mei (1992), table 1 reveals that the converse situation exists with respect to Japanese real estate and stocks. US real estate exhibits a lower volatility in returns relative to US stocks because equity REITs are required by law to pay out 95 percent of their earnings as dividends. Japanese real estate companies have a higher return volatility relative to stocks in contrast. This is probably due to the practice that they have of using the run-up in the price of their underlying real estate to borrow additional money and reinvesting these funds in the stock market as a method of generating additional profits. In addition to this, both real estate and stocks in Japan have higher returns and risk on average relative to their US counterparts, which is not surprising given the spectacular rise in prices for Japanese stocks and real estate relative to US stocks and real estate, and the fact that Japanese firms tend to have higher debt to equity ratios in general relative to US firms. Table 1 also reveals that the returns on all asset categories exhibit positive first-order autocorrelation with the returns on real estate securities in the US and Japan having a relatively higher positive serial correlation. This suggests that the return on real estate in both countries tends to be more predictable relative to stocks. Although real estate and stock returns are moderately correlated within a particular country, intercountry correlations among asset returns are low.

The results of regressing the mean adjusted real stock returns on eight forecasting variables (the lag of the real return on US and Japanese real estate and stocks in addition to the return on government bonds and the dividend yield) are reported in table 2 for a VAR(1) process. Table 2 shows that the returns for stocks and real estate in the US and Japan are predictable, with real estate in both countries more predictable, relative to stocks, which is consistent with the positive serial correlations in table 1. In fact, approximately 17 (7) percent of the variation in returns on Japanese (US) real estate securities are predictable. In contrast, US and Japanese stocks are less predictable with 6.8 and 5.9 percent of the variation in these returns, respectively, being predictable. Surprisingly, the lagged return on US real estate is influential in forecasting future US stock returns. US dividend yields lagged are also significant 
in predicting both future stock and real estate returns in the US. Neither lagged returns on US stocks and real estate nor lagged returns on Japanese real estate, in contrast, have an impact on future US real estate returns, although Japanese stock returns are of marginal significance in forecasting returns on US real estate. The converse situation exists with respect to returns on Japanese stocks and real estate. Lagged returns on Japanese stocks are useful in predicting future returns on Japanese real estate. One plausible explanation for this as stated earlier is the fact that profits for Japanese real estate firms are closely linked to the stock market movements since these asset-rich companies have borrowed on their real estate equity and have invested the proceeds in the stock market to generate additional profits. The only cross-country effect is that lagged US stock returns are useful in anticipating future returns on Japanese stocks, which supports the prior findings of Hamao et al. (1990) and Campbell and Hamao (1989) that the Japanese stock market is more sensitive to foreign shocks compared with the US stock market. The short-term Japanese bill is not an important factor in predicting returns on either US or Japanese assets, while the US T-bill is only marginally significant in predicting future real estate returns in both countries.

Table 1. Summary statistics

\begin{tabular}{|c|c|c|c|c|c|c|c|c|}
\hline & & & & & & Mean & $S D$ & $\rho_{1}$ \\
\hline \multicolumn{9}{|c|}{ Dependent variables: } \\
\hline \multicolumn{6}{|c|}{ Real return on US stock portfolio (USStk) } & 0.387 & 4.81 & 0.057 \\
\hline \multicolumn{6}{|c|}{ Real return on US real estate portfolio (USRE) } & 0.392 & 4.13 & 0.128 \\
\hline \multicolumn{6}{|c|}{ Real return on Japanese stock portfolio (JPStk) } & 0.978 & 6.63 & 0.091 \\
\hline \multicolumn{6}{|c|}{ Real return on Japanese real estate portfolio (JPRE) } & 0.532 & 7.57 & 0.288 \\
\hline \multicolumn{6}{|c|}{ Nominal return on US T-Bills (USTBill) } & 0.079 & 1.61 & 0.738 \\
\hline \multicolumn{6}{|c|}{ Nominal return on US dividend yield (USDYld) } & 4.117 & 0.88 & 0.967 \\
\hline \multicolumn{6}{|c|}{ Nominal return on Japanese T-bills (JPTBill) } & 0.041 & 4.19 & 0.209 \\
\hline \multicolumn{6}{|c|}{ Nomilnal return on Japanese dividend yield (JPDYld) } & 1.623 & 0.78 & 0.994 \\
\hline \multicolumn{9}{|c|}{ Correlations: } \\
\hline & USStk & USRE & $J P S t k$ & $J P R E$ & USTBill & USDYld & JPTBill & JPDYld \\
\hline USStk & 1.00 & & & & & & & \\
\hline USRE & 0.64 & 1.00 & & & & & & \\
\hline$J P S t k$ & 0.31 & 0.26 & 1.00 & & & & & \\
\hline$J P R E$ & 0.17 & 0.15 & 0.69 & 1.00 & & & & \\
\hline USTBill & -0.24 & -0.23 & -0.07 & -0.14 & 1.00 & & & \\
\hline USDYld & 0.13 & 0.13 & -0.08 & -0.04 & -0.09 & 1.00 & & \\
\hline JPTBill & -0.06 & -0.08 & 0.40 & 0.42 & -0.03 & 0.04 & 1.00 & \\
\hline JPDYld & -0.05 & 0.04 & 0.02 & -0.03 & 0.00 & 0.34 & -0.02 & 1.0 \\
\hline
\end{tabular}

Notes: The sample period for this table is $1972.02-1992.02$, with 240 observations. Units on returns are percentage per month with the real returns on Japanese stock and real estate denominated in US dollars. $\rho_{1}$ is the first autocorrelation of the series.

To further examine the cross-country relations, we also run the regression of table 1 with only own country variables. The last column of table 1 presents the $R 2$ using only own-country variables. By comparing it with the $R 2$ using both countries, we can see the marginal contribution of the cross-country effect. As we can see from table 1, the impact of Japanese markets on the US market was relatively 
small. On the other hand, there is some evidence that the US equity market had some significant impact on the Japanese equity market. Overall, a simple Granger test reveals no evidence of the Japanese market Granger-causing US market movements and only weak evidence of the US market Grangercausing Japanese market movements.

Table 2. Basic VAR results for real returns on Japanese and US stocks using generalized method of moments (one lag, monthly; period 1972.02 to 1992.02 )

\begin{tabular}{|c|c|c|c|c|c|c|c|c|c|c|c|c|}
\hline $\begin{array}{l}\text { Dependent } \\
\text { variable }\end{array}$ & $U S S t k_{t}$ & $U S R E_{t}$ & $J P S t k_{t}$ & $J P R E_{t}$ & USTBill $_{t}$ & USDYld $d_{t}$ & JPTBill $_{t}$ & $J P D Y l d_{t}$ & $R^{2}$ & $p$-value & $D W$ & $R_{\text {(own) }}^{2}$ \\
\hline$U S S t k_{t+1}$ & $\begin{array}{l}-0.127 \\
(-1.39)\end{array}$ & $\begin{array}{c}0.198 \\
(2.18)\end{array}$ & $\begin{array}{c}0.053 \\
(0.82)\end{array}$ & $\begin{array}{c}0.013 \\
(0.20)\end{array}$ & $\begin{array}{c}-0.260 \\
(-1.38)\end{array}$ & $\begin{array}{c}0.936 \\
(2.35)\end{array}$ & $\begin{array}{c}0.027 \\
(0.34)\end{array}$ & $\begin{array}{l}-0.782 \\
(-1.81)\end{array}$ & 0.068 & 0.04 & 1.98 & 0.046 \\
\hline$U S R E_{t+1}$ & $\begin{array}{l}-0.020 \\
(-0.28)\end{array}$ & $\begin{array}{c}0.044 \\
(0.48)\end{array}$ & $\begin{array}{r}0.087 \\
(1.55)\end{array}$ & $\begin{array}{c}0.041 \\
(0.92)\end{array}$ & $\begin{array}{l}-0.279 \\
(-1.65)\end{array}$ & $\begin{array}{r}0.767 \\
(2.02)\end{array}$ & $\begin{array}{l}-0.084 \\
(-1.17)\end{array}$ & $\begin{array}{l}-0.091 \\
(-0.22)\end{array}$ & 0.074 & 0.02 & 1.99 & 0.048 \\
\hline$J P S t k_{t+1}$ & $\begin{array}{r}0.267 \\
(2.18)\end{array}$ & $\begin{array}{c}0.031 \\
(0.25)\end{array}$ & $\begin{array}{l}-0.008 \\
(-0.07)\end{array}$ & $\begin{array}{r}0.067 \\
(0.74)\end{array}$ & $\begin{array}{l}-0.171 \\
(-0.65)\end{array}$ & $\begin{array}{l}-0.402 \\
(-0.76)\end{array}$ & $\begin{array}{c}-0.096 \\
(-0.78)\end{array}$ & $\begin{array}{r}0.323 \\
(0.54)\end{array}$ & 0.059 & 0.09 & 2.02 & 0.019 \\
\hline$J P R E_{t+1}$ & $\begin{array}{r}0.187 \\
(1.52)\end{array}$ & $\begin{array}{c}0.080 \\
(0.61)\end{array}$ & $\begin{array}{r}0.297 \\
(2.60)\end{array}$ & $\begin{array}{r}0.107 \\
(1.10)\end{array}$ & $\begin{array}{l}-0.428 \\
(-1.55)\end{array}$ & $\begin{array}{r}0.273 \\
(0.51)\end{array}$ & $\begin{array}{l}-0.136 \\
(-1.07)\end{array}$ & $\begin{array}{l}-0.223 \\
(-0.36)\end{array}$ & 0.174 & 0.00 & 1.95 & 0.136 \\
\hline USTBill $_{t+1}$ & $\begin{array}{c}0.006 \\
(0.21)\end{array}$ & $\begin{array}{l}-0.024 \\
(-0.90)\end{array}$ & $\begin{array}{c}-0.004 \\
(-0.28)\end{array}$ & $\begin{array}{c}-0.008 \\
(-0.76)\end{array}$ & $\begin{array}{r}0.709 \\
(12.85)\end{array}$ & $\begin{array}{l}-0.158 \\
(-1.60)\end{array}$ & $\begin{array}{l}-0.061 \\
(-2.67)\end{array}$ & $\begin{array}{r}0.068 \\
(0.83)\end{array}$ & 0.589 & 0.00 & 1.94 & 0.550 \\
\hline$U S D Y l d_{t+1}$ & $\begin{array}{c}-0.043 \\
(-25.34)\end{array}$ & $\begin{array}{l}-0.003 \\
(-1.91)\end{array}$ & $\begin{array}{c}0.002 \\
(2.24)\end{array}$ & $\begin{array}{r}0.001 \\
(0.55)\end{array}$ & $\begin{array}{l}-0.001 \\
(-0.16)\end{array}$ & $\begin{array}{r}1.002 \\
(129.67)\end{array}$ & $\begin{array}{l}-0.003 \\
(-1.96)\end{array}$ & $\begin{array}{c}-0.010 \\
(-1.39)\end{array}$ & 0.991 & 0.00 & 2.36 & 0.991 \\
\hline$J P T B i l l_{t+1}$ & $\begin{array}{r}0.082 \\
(1.08)\end{array}$ & $\begin{array}{l}-0.025 \\
(-0.32)\end{array}$ & $\begin{array}{l}-0.124 \\
(-2.14)\end{array}$ & $\begin{array}{l}-0.098 \\
(-1.79)\end{array}$ & $\begin{array}{l}-0.100 \\
(-0.49)\end{array}$ & $\begin{array}{c}0.001 \\
(0.00)\end{array}$ & $\begin{array}{r}0.363 \\
(4.28)\end{array}$ & $\begin{array}{l}-0.082 \\
(-0.26)\end{array}$ & 0.129 & 0.00 & 2.11 & 0.121 \\
\hline$J P D Y l d t_{+1}$ & $\begin{array}{l}-0.000 \\
(-0.37)\end{array}$ & $\begin{array}{l}-0.000 \\
(-0.31)\end{array}$ & $\begin{array}{r}-0.012 \\
(-11.94)\end{array}$ & $\begin{array}{r}0.001 \\
(2.31)\end{array}$ & $\begin{array}{r}0.001 \\
(0.77)\end{array}$ & $\begin{array}{c}0.004 \\
(0.97)\end{array}$ & $\begin{array}{r}0.007 \\
(7.52)\end{array}$ & $\begin{array}{c}0.986 \\
(163.7)\end{array}$ & 0.996 & 0.00 & 1.62 & 0.991 \\
\hline
\end{tabular}

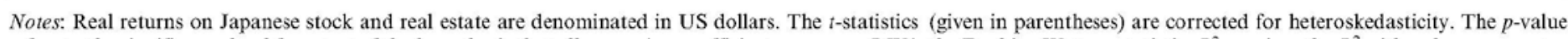

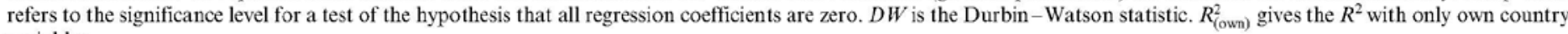
variables.

To determine the lag length used in the VAR process, we performed a joint Wald test of including an additional lag in our VAR(1) model. Our test reveals that, while a second lag of some variables is significant, the joint test cannot reject the hypothesis that the coefficients on the second lag are jointly zero. ${ }^{9}$

We therefore use a VAR(I) process and alternatively use a VAR (2) process to decompose the variance of real asset returns into the variance of contemporaneous expected asset returns and the variance of unexpected asset returns. A decomposition of this risk in table 3 reveals that the variance of contemporaneous expected asset returns accounts for only a minimal portion of the total variation associated with the return on each asset class regardless of whether a VAR(I) or VAR (2) process is used. The only exception to this is for Japanese real estate. The volatility of contemporaneous expected returns on Japanese real estate accounts for 17.4-21.2 percent of the total real estate risk. Movements in contemporaneous expected returns on US assets and Japanese stocks, in contrast, account for a much lower portion (5.9-11.8 percent) of the total risk for these asset classes. Consequently, the variance of

\footnotetext{
${ }^{9}$ A test on the significance of a VAR (3) process is not possible owing to lack of degrees of freedom. In our study, we present results for both $\operatorname{VAR}(I)$ and $\operatorname{VAR}(2)$.
} 
unexpected returns accounts for most of the variance in total returns for both US and Japanese assets, which is consistent with the evidence in the US market.

Table 3. Decomposition of the total variance of real US and Japanese asset returns (decomposed into variances of expected and unexpected asset returns)

\begin{tabular}{|c|c|c|c|c|}
\hline & $R^{2}$ & $\begin{array}{c}\text { Total } \\
\text { variance }\left(\sigma^{2}\right)\end{array}$ & $\begin{array}{c}\text { Expected } \\
\text { variance }\left(\sigma_{E}^{2}\right)\end{array}$ & $\begin{array}{c}\text { Unexpected } \\
\text { variance }\left(\sigma_{E}^{2}\right)\end{array}$ \\
\hline \multicolumn{5}{|l|}{$V A R$ (1) process } \\
\hline US stocks & 0.068 & 23.136 & 1.573 & 21.563 \\
\hline US real estate & 0.074 & 17.057 & 1.262 & 15.795 \\
\hline Japanese stocks & 0.059 & 43.957 & 2.594 & 41.363 \\
\hline Japanese real estate & 0.174 & 57.305 & 9.971 & 47.334 \\
\hline \multicolumn{5}{|l|}{$V A R$ (2) process } \\
\hline US stocks & 0.118 & 23.136 & 2.730 & 20.406 \\
\hline US real estate & 0.114 & 17.057 & 1.945 & 15.112 \\
\hline Japanese stocks & 0.094 & 43.957 & 4.145 & 39.812 \\
\hline Japanese real estate & 0.212 & 57.305 & 12.149 & 45.156 \\
\hline
\end{tabular}

Notes: $\sigma^{2}$ is defined as the variance of total real returns for each asset. This variance can be decomposed into two components: $\sigma_{E}^{2}$ which is defined as the variance of expected asset returns, and $\sigma_{\varepsilon}^{2}$ which represents the unexplained variance of the residual term associated with each equation in the VAR system, or alternatively the variance of the unexpected asset returns. By definition, the covariance between expected and unexpected asset returns is zero. $R^{2}$ represents the variation in total asset returns which is accounted for by the $\operatorname{VAR}(n)$ process, where $n$ is the number of lags.

The variance of unexpected asset returns associated with each equation in the VAR system, denoted $a 2 s$, is further partitioned into three components in table 4 . The three components are the news about future cash flows or cash flow risk, $\left(\operatorname{Var}\left(\eta_{\mathrm{d}}\right)\right)$, the future expected return or discount rate risk, $\left(\operatorname{Var}\left(\eta_{d}\right)\right)$, and the covariance between future cash flow risk and discount rate risk $\left(\operatorname{Cov}\left(\eta_{d}, \eta_{h}\right)\right)$. For easier interpretation, the three terms $\operatorname{Var}\left(\eta_{d}\right), \operatorname{Var}\left(\eta_{h}\right)$ and $-2 \operatorname{Cov}\left(\eta_{d}, \eta_{h}\right)$ are given as ratios to the variance of the unexpected real returns so that they sum to one. Table 4 reveals that, although cash flow risk accounts for the largest portion of the variance in unexpected returns for all Japanese assets, it is not statistically significant owing to large estimation errors. Moreover, news about future expected returns also has no statistically significant impact on Japanese asset returns.

Returns on US stocks and real estate, in contrast, are influenced by news on future expected returns although the impact of this news is not statistically significant for real estate. News about future cash flows however, is significant for US real estate returns. This is consistent with the fact that equity REITs are required to pay out 95 percent of their earnings. Changes in future expected cash flows for equity REITs could arise in part from changing expectations in future rental rates, anticipated vacancies, and tentative absorption rates. The $\operatorname{Corr}\left(\eta_{d}, \eta_{h}\right)$ column of table 4 also reveals that good news about changes in future cash flows tends to be strongly associated with increases in expected future returns (discount rate) for US and Japanese securities except for US stocks for a VAR(1) process. This means that 
whenever there is good news about future cash flow, investors will tend to become apprehensive about the future and thus demand higher expected future returns. The net effect of this phenomenon is that it tends to dampen the shock of future cash flow news and future discount rate news to the market because they work in opposite directions. ${ }^{10}$ News about future cash flow is good for the current asset price, while news about future expected return is bad for the current asset price. This phenomenon is consistent with stocks and real estate in the US and Japan (except for US stocks for a VAR(I) process). However, the correlation is only significant for real estate returns in the US and Japan.

A persistence measure $P_{h}$ is also computed in the last column of table 4 using equation (7). This measure of persistence measures the capital loss on a stock given a positive innovation in the discount rate (e.g. a typical 1 percent positive innovation in the future expected return (discount rate) is associated with a $P_{h}$ percent decline in value on the stock). The higher the $P_{h}$ value, the more persistent over time are the changes in expected return. This measure of persistence differs from $R^{2}$, in that the latter measures the ability to forecast expected returns in the next period $(\mathrm{t}+1)$ whereas $P h$ measures how persistent over time $(t+1, \ldots, t+T)$ are changes in the expected rate of return or discount rate, e.g. for how many periods a positive (negative) drift occurs in expected returns. The persistence measure reveals that changes in the future expected return (discount rate) for Japanese stocks and real estate are less persistent over time than their US counterparts (cf. Campbell, 1991). This means that even though the expected returns for Japanese assets are high today, it is unlikely that these expected returns will remain high tomorrow. The temporary nature of changes in the discount rate for Japanese assets implies that the forecasted changes in expected return will have a smaller impact on current price of, and therefore current returns on, Japanese stock and real estate. This is consistent with the above result in table 4 that news about future expected return explains a small portion of $\sigma$ in Japan.

Figures 1 and 2 provide plots of the variance ratio calculations for US and Japanese asset returns using a $\operatorname{VAR}(1)$ and $\operatorname{VAR}(2)$ process, respectively. As stated earlier in this paper, the variance ratio is equal to 1 for white noise returns (i.e. there is no serial correlation in the return series), it exceeds 1 when returns are mostly positively autocorrelated, and it is below 1 when negative autocorrelations dominate. The variance ratios are calculated using six-month intervals and go from six to 90 months. Figure 2 reveals that the variance ratios are always greater than 1 and are increasing steadily over the seven-year horizon for Japanese real estate, implying that the autocorrelations for all holding-period returns are dominantly positive. Returns on Japanese real estate display some evidence of negative serial correlation when a VAR(1) process is employed. Returns on Japanese stock and US real estate take

\footnotetext{
${ }^{10}$ It is worth noting that the above results on US equities are similar to those discovered in Campbell (1990).
} 
a longer time to display negative autocorrelations relative to US stock returns. In addition to this, the returns on Japanese assets show signs of negative autocorrelation much more slowly when compared with the mean reversion process for US assets. This result is not unexpected given our earlier finding that Japanese capital markets are mainly driven by news on future cash flows and are therefore much less influenced by news on future expected returns which are more likely to be affected by market overreaction or the changing perception of risk by investors. ${ }^{11}$ This finding is consistent with prior evidence for US capital markets that negative autocorrelations (or mean reversion) exist for longhorizon returns even though mean reversion is much weaker for real estate relative to stocks (cf. Campbell, 1990; Cochrane, 1988; Kandel and Stambaugh, 1988; Lo and MacKinlay, 1988; Poterba and Summers, 1988; and more recently Liu and Mei, 1994).

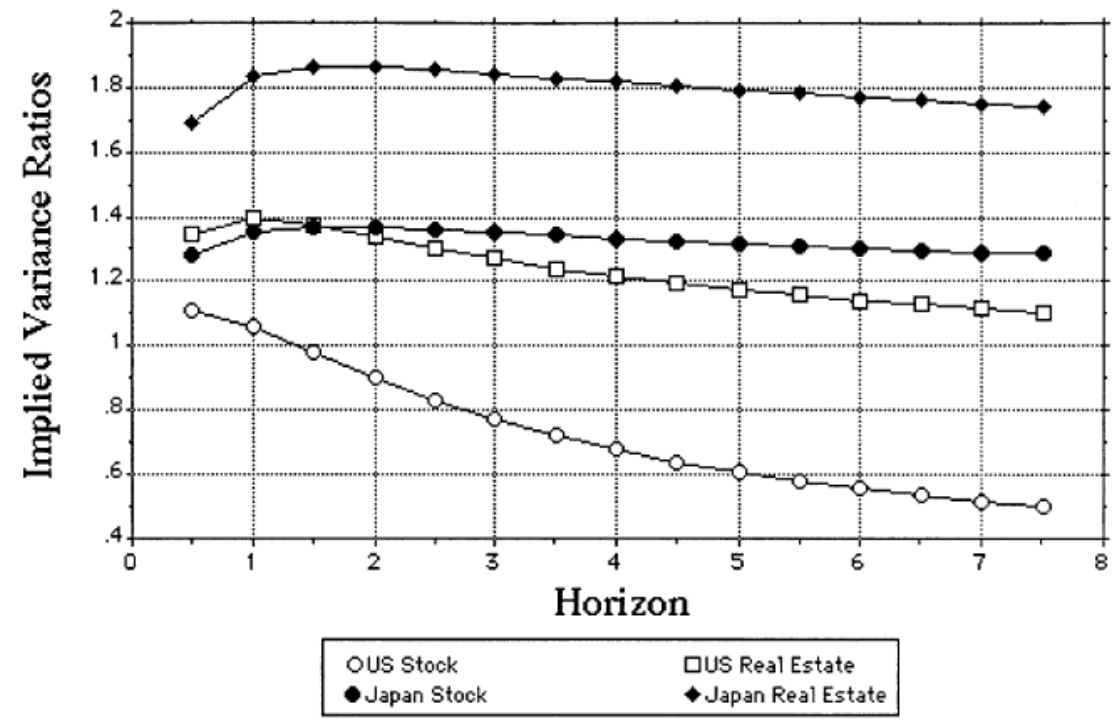

Figure 1. Implied variance ratios using a VAR (1) process

\footnotetext{
${ }^{11}$ From the perspective of market timing, this implies that contrarian strategists who want to exploit mean reversion have to be more patient with the Japanese market, since there is little evidence of negative serial correlation in the short run.
} 


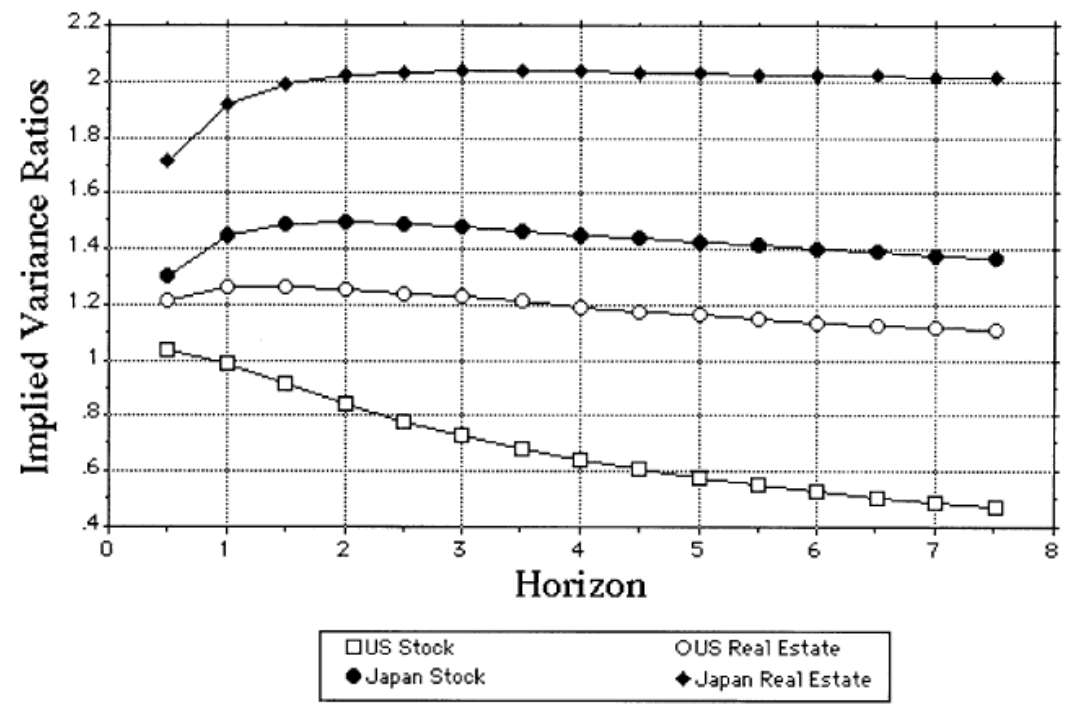

Figure 2. Implied variance ratios using a VAR (2) process

\section{Summary and Conclusions}

The current study offers evidence that returns on Japanese stocks and real estate do not necessarily exhibit behavior parallel to their US counterparts. In particular, we find that current Japanese stock returns are useful in predicting future expected returns on Japanese real estate. Existing returns on US real estate, in contrast, are valuable in forecasting future anticipated returns on US stocks. One distinguishing intercountry aspect is that changes in the future expected returns are less persistent over time for Japanese assets relative to their US counterparts, which suggests that changes in the future expected returns have a lesser impact on current prices for Japanese assets relative to US assets. Another distinguishing characteristic is that the return on Japanese stocks and real estate exhibit a weaker negative serial correlation (or mean reversion) compared with returns on US assets over the periods examined. However, our study does find some parallels between stocks and real estate in the US and Japan. Not only are the returns on real estate more predictable relative to stock returns, but also changes in the expected return on real estate are more persistent over time compared with stocks in both countries. The negative serial correlation for real estate is also found to be weaker compared with stocks across both the US and Japan. 


\section{Appendix: The Dividend-Ratio Model}

Campbell and Shiller (1988) use a first-order Taylor series approximation of the log of the holding-period return equation, $h_{t+1}=\log \left[\left(P_{t+1}+D_{t+1}\right) / P_{t}\right]$ to obtain the following equation:

$$
h_{t+1} \approx k+\delta_{t}-\rho \delta_{t+1}+\Delta d_{t+1}
$$

where $h_{t+1}$ is the asset return in period $t+1, d_{t}$ is the log of the real dividend paid during period $t, S t$ is the log dividend/price ratio $d_{t} / p_{t} p_{t}$ is the log real stock price at the end of period $t, p$ is the average ratio of the stock price to the sum of the stock price and the dividend, and the constant it is a nonlinear function of $p .{ }^{12}$ The log dividend/price ratio model $\delta_{\mathrm{t}}$ is next obtained by treating equation (Al) as a difference equation relating $\delta_{t}$ to $\delta_{t+1} \Delta d_{t+1}$ and $h_{t}+h$ and then solving this equation forward imposing the terminal condition that $\delta_{t+i}$ does not explode as $i$ increases $\left(\lim _{i} \rightarrow p^{i} \delta_{t+1}\right)$. The resulting log dividend/price equation is

$$
\delta_{t}=\sum_{j=0}^{\infty} \rho^{j}\left(h_{t+1+j}-\Delta d_{t+j+j}\right)-\frac{k}{1-\rho} .
$$

Equation (A2) represents the present-value of all future returns, $h_{t+j}$, and dividend growth rates, $\Delta d_{t+j}$ discounted at the constant rate $p$, with a constant $k /(1-p)$ subtracted from this result; it implies that if the dividend yield is currently large, high future returns will occur unless dividend growth is low in the future. Although all of the variables in (A2) are measured ex post, (A2) also holds ex ante. Consequently, equation (1) in the paper obtains if we use the ex ante version of equation (A2) to substitute $\delta$, and $\delta_{t+1}$ out of $(\mathrm{Al}) .^{13}$

\section{References}

Boone, P. and S. Jeffrey (1989) "Is Tokyo Worth Four Trillion Dollars? An Explanation for High Japanese Land Prices," Working Paper, Harvard University.

\footnotetext{
${ }^{12}$ The equations used in the current study differ slightly from those used in Campbell and Shiller (1988) owing to a difference in timing conventions. More specifically, we assume that the stock price at time $t$ and the conditional expectation of future variables are measured at the end of period $t$ rather than at the beginning of period $t$. ${ }^{13}$ This follows from the fact that $\mathrm{St}$ is unchanged on the left-hand side of equation (A2) if we take expectations of equation (A2), conditional on information available at the end of time period $t$ because 6 , is in the information set and the right-hand side of equation (A2) becomes an expected discounted value. See Campbell and Shiller (1988) for an evaluation of the quality of the linear approximation in equations (Al) and (A2).
} 
Brown, S. and T. Otsuki (1990) "Macroeconomic Factors and the Japanese Equity Markets: The CAPMD Project," in Edwin Elton and Martin Gruber (eds), Japanese Capital Markets, New York: Harper \& Row.

Campbell, J. (1987) "Stock Returns and the Term Structure," Journal of Financial Economics 18, 373-99. (1990) "Measuring the Persistence of Expected Returns," American Economic Review Papers and Proceedings 80, 43-7'. (1991) "A Variance Decomposition of Stock Returns," Economic Journal 101, 157-79.

Campbell and Ammer (1991).

Campbell, J. and Y. Hamao (1989) "Predictable Stock Returns in the US and Japan: A Study of Long-Term Capital Market Integration," Journal of Finance.

Campbell and Mei (1991).

Campbell, J. and R. Shiller (1988) "The Dividend-Price Ratio and Expectations of Future Dividends and Discount Factors," Review of Financial Studies 1, 195-228.

Cochrane (1988).

Elton and Gruber (1990).

Fama, E. and K. French (1989) "Business Conditions and Expected Return on Stocks and Bonds," Journal of Financial Economics 25, 23-49.

Fisher, J. D., R. B. Webb and D. Geltner (1991) "Historical Value Indices of Commercial Real Estate", Working Paper, University of Indiana.

Gyourko, J. and D. Keim (1992) "What Does the Stock Market Tell Us About Real Estate Returns?" AREUEA Journal 20, 457-86.

Hamao, Y. (1989) "Japanese Stocks, Bonds, Bills, and Inflation, 1973-87," Journal of Portfolio Management 15, 20-6.

Hamao, Y. and T. Hoshi (1991) "Stock and Land Prices in Japan," Working Paper, Columbia University.

Hamao, Y., R. Masulis and V. Ng. (1990) "Correlations in Price Changes and Volatility Across International Stock Markets," Review of Financial Studies, 3, 281-308.

Itoshi (1991).

Kandel and Stambaugh (1988).

Liu, C. and J. Mei (1992) "The Predictability of Returns on Equity REITS and their Co-movement with Other Assets," Journal of Real Estate Finance and Economics 5, 401-8. (1994) "An Analysis of Real Estate Risk using the Present Value Model," Journal of Real Estate Finance and Economics 8, 
5-20. (1998) "Evidence of the Integration of International Real Estate Market and Diversification Consequences," Real Estate Economics, forthcoming.

Lo and MacKinlay (1988).

McElroy and Burmeister (1988).

Mei, J. and A. Lee (1994) "Is There a Real Estate Factor Premium?" Journal of Real Estate Finance and Economics 8, 113-26.

Poterba and Summers (1988). 